\title{
Distributional patterns of Aptian-Albian paleoichthyofauna of Brazil and Africa based on Track Analysis*
}

\section{THAÍS C.C. PARMÉRA ${ }^{1}$, VALÉRIA GALLO ${ }^{1}$, HILDA M.A. DA SILVA ${ }^{1}$ and FRANCISCO J. DE FIGUEIREDO ${ }^{2}$}

\author{
${ }^{1}$ Laboratório de Sistemática e Biogeografia, Departamento de Zoologia, Instituto de Biologia, Universidade do \\ Estado do Rio de Janeiro, Rua São Francisco Xavier, 524, Maracanã, 20550-013 Rio de Janeiro, RJ, Brazil \\ ${ }^{2}$ Laboratório de Ictiologia, Departamento de Zoologia, Instituto de Biologia, Universidade do Estado do \\ Rio de Janeiro, Rua São Francisco Xavier, 524, Maracanã, 20550-013 Rio de Janeiro, RJ, Brazil
}

Manuscript received on July 25, 2016; accepted for publication on September 7, 2016

\begin{abstract}
How to cite: PARMÉRA TCC, GALLO V, SILVA HM AND FIGUEIREDO FJ. 2019. Distributional patterns of Aptian-Albian paleoichthyofauna of Brazil and Africa based on Track Analysis. An Acad Bras Cienc 91: e20160456. DOI 10.1590/0001-3765201720160456.
\end{abstract}

\begin{abstract}
The Aptian-Albian paleoichthyofauna in Brazil and Africa is quite diverse, yet their geographic patterns still require accounts. This work consists of a panbiogeographical analysis of paleoichthyofauna from Aptian-Albian through track analysis. Geographic coordinates were obtained and converted into paleocoordinates. Individual Tracks (ITs) and Generalized Tracks (GTs) were built with the aid of ArcView GIS v3.2 program using Trazos2004 extension. As a result, four GTs and tree Biogeographic Nodes (A, $\mathrm{B}$ and $\mathrm{C}$ ) had been identified. GTs 1 and 2 shows two different faunas. GT3 indicates similarity between Brazil and Africa paleoichthyofauna suggesting the break-up of Gondwana as the event that separated it. GT4 represents a probable local seaway produced by transgressions. In the Node A a unique fauna was found indicating the presence of a third biota with its own characteristics. Node B is associated with the break-up of the supercontinent Gondwana. Node $\mathrm{C}$ was related to fauna exchange promoted by marine ingression and epicontinental seas that occurred during Aptian-Albian. We concluded that there is a relationship between the distributional patterns of biota and events such as the break-up of Gondwana, the formation of Atlantic Ocean and eustatic movements that affected South America and Africa.
\end{abstract}

Key words: Aptian-Albian, Gondwana Break-up, historical biogeography, track analysis.

\section{INTRODUCTION}

The paleoichthyofauna of the Cretaceous, mainly restricted to the Aptian-Albian, is diversified and known since 19th century (e.g., Agassiz 1841, Jordan and Branner 1908, Woodward 1908, Jordan

Correspondence to: Valéria Gallo

E-mail: gallo@uerj.br

ORCid: http://orcid.org/0000-0003-1766-4084

* Contribution to the centenary of the Brazilian Academy of Sciences.
1910, 1919, Schaeffer 1947, Silva Santos 1985a, b, c, Maisey 1991, Figueiredo and Gallo 2004, Santos and Carvalho 2009, Brito et al. 2013).

The Aptian-Albian assemblages possess many fossil representatives in Brazilian marginal and interior basins and these have been used to illustrate the relationships between South America and Africa (Maisey 1993, 2000). Furthermore, divergence of several taxa may have occurred before continental drift (Lundberg 1993). Brazilian fossil records of this age range come from several basins, such as 
Araripe, Parnaíba, Pernambuco-Paraíba, Potiguar, Sanfranciscana, São Luís, Sergipe-Alagoas and Tucano, and include many taxa (e.g., †Lepidotes, $\uparrow$ Vinctifer comptoni, †Dastilbe crandalli, $\uparrow$ Rhacolepis buccalis).

The Araripe Basin is an interior basin located in Northeast Brazil. Its Aptian-Albian sequence is represented by the Crato and Santana formations, respectively, and they indicate the post-rift stage. The paleoenvironments found in these lithostratigraphic units are lacustrine, coastal and platform, being composed of shales, limestones and sandstones (Assine 2007).

The Codó Formation represents the AptianAlbian section of the Parnaíba Basin. Shales, limestones, siltstones, sandstones, gypsite and anhydrite are the main lithotypes found in this unit, suggesting lacustrine, shallow marine, and fluviodeltaic paleoenvironments (Vaz et al. 2007).

The Cabo Formation encompasses the AptianAlbian interval of the Pernambuco-Paraíba Basin. This lithostratigraphic unit comprises shales, sandstones and conglomerates and the paleoenvironment proposed is lacustrine with alluvial fans (Córdoba et al. 2007).

The Aptian-Albian interval in the Potiguar Basin is represented by the Açu Formation, whose paleoenvironment was identified as transgressive marine with sandstones and shales (Neto et al. 2007a).

The Areado Formation represents the AptianAlbian sequence from the Sanfranciscana Basin. This unit is constituted by shales, sandstones and conglomerates, which correspond to the rift stage. The paleoenvironments are interpreted as lacustrine, fluvial and desert (Zalán and Silva 2007).

The interval in the São Luís Basin is represented by the Itapecuru Formation, which consists of shales, siltstones and sandstones from fluvial, alluvial and coastal paleoenvironments during the rift stage of break-up (Zalán 2007).

In the Sergipe-Alagoas Basin, the Aptian-Albian interval is composed of the Maceió, Muribeca and Riachuelo formations. Sandstones, shales and calcisiltites are found in these units, and correspond to rift, post-rift and drift stages. Paleoenvironments are interpreted as alluvial-fluvial, deltaic-lacustrine and marine (Neto et al. 2007b).

The Tucano Basin includes the Marizal Formation with sandstones and conglomerates from an alluvial paleoenvironment produced during the post-rift stage (Costa et al. 2007a, b).

The Cocobeach Group belongs to the Gabon Basin and consists of interbedded and laterally gradational fluvial sandstones and lacustrine shales. Turbidites are interbedded with the latter. The unit was deposited in a series of nonmarine rift basins formed due to the onset of rifting between Africa and South America (Ala and Selley 1997).

The strata of Iullemmeden Basin are known as Continental Intercalaire (Greigert 1966, Moody and Sutcliffe 1991). The Continental Intercalaire is divided into three groups: Agadez, Irhazer and Tegama (Moody and Sutcliffe 1991). The paleovertebrate fauna of the Aptian-Albian portion belongs to Irhazer Group, whose strata are predominantly composed by shales with localized bars of fine-grained calcareous sandstones. The fine-grained nature and extensive lateral distribution of the siltstones indicate a low energy fluvio-lacustrine depositional paleoenvironment (Moody and Sutcliffe 1991).

The Tataouine Basin is divided in three formations: Douiret, Aïn el Guettar and Zebbag (Bouaziz et al. 1988, Zarbout et al. 1994). Vertebrate fossils are found in the conglomeratic beds from the Douiret and Aïn el Guettar formations, which are dated as Aptian and Albian, respectively. The paleoenvironment of Douiret Formation is interpreted as fluvial, whereas in the Aïn el Guettar Formation it is considered shallow marine (Anderson et al. 2007).

The Galula Formation is included in Rukwa Rift Basin and is composed of red sandstones, conglomerates and mudstones. This formation comprises a large grain size range of sediments 
besides having an alluvial architecture and lithofacies (Roberts et al. 2010).

Historical biogeography allows recognize the distribution of taxa and their areas of endemism. This approach is essential when fossil groups are considered (Morrone and Crisci 1995, Gallo and Figueiredo 2010).

The Panbiogeographic methods (Croizat 1958, 1964) allow to recovery the distributional patterns of taxa considering their geographical occurrence as well as the geological history of areas. Its basic track analysis method specifies the evolution of different groups and areas if they share a common history among their distributions over time. Such patterns can be recognized by events of wide scale, which mainly comprise vicariant and extinction hypotheses (Crisci 2001). Furthermore, Panbiogeography can be applied to paleontological data (Gallo et al. 2007), and according to Croizat (1958, 1964) distributions of fossil and living taxa should be integrated in the same analysis. In addition, data related to paleogeographic distributions allow to recreate ancient explanatory scenarios (Upchurch 2008).

Carvalho (2009) stated that Panbiogeography is a useful tool to analyze distributional patterns of biota and he wrote that it represents a "robust, objective, empirically testable, fast, low-cost method, based on available taxonomic information".

Some studies have been developed using geographic distributions of fossil fish applying methods of historical biogeography (e.g., Gallo et al. 2007, Silva and Gallo 2007, Miguel et al. 2014). Gallo et al. (2007) analyzed the distributional patterns of Turonian marine biotas, including several fish taxa (e.g., lamniforms, pycnodontiforms, ichthyodectiforms, crossognathiforms, salmoniforms and aulopiforms). The authors concluded that final break-up of Gondwana and Laurasia was determinant vicariant event for biogeography of Atlantic Ocean and shaped the distributions of the Turonian biota. Silva and Gallo (2007) employed Parsimony
Analysis of Endemicity to analyze the distribution of enchodontoid fishes occurring only in the Cenomanian. The authors delimited two areas of endemism in Tethys Ocean. The first was composed of Morocco and southern Italy whereas the latter comprises Lebanon and Israel.

Miguel et al. (2014) identified distributional patterns of mawsoniid fishes, applying the panbiogeographical method of track analysis. The authors concluded that tectonic events related to the break-up of Pangaea and Gondwana and the evolution of Atlantic Ocean were vicariant events that shaped the distribution of this taxon throughout the Mesozoic.

The goal of this study was to identify the distributional patterns of the ichthyofauna within the Aptian-Albian interval ( 125 to 100 Mya). Furthermore, we tested Souza-Lima's $(2006,2007)$ hypothesis regarding the formation of the Proto-South Atlantic due to the crustal distension of Gondwana from Jurassic, where currently Sergipe-Alagoas, Camamu, Almada and Cumuruxatiba basins are found, and then simultaneously opening towards the north and south, in Pernambuco-Paraíba, Espírito Santo, Campos, Santos and Pelotas basins.

\section{MATERIALS AND METHODS}

We listed geographical occurrences of the ichthyofauna within the Aptian-Albian interval obtained from the Paleontological Collection of Instituto de Biologia Roberto Alcantara Gomes, Universidade do Estado do Rio de Janeiro, as well as from the analysis of literature, supplemented by records of the website Paleobiology Database (http://www. paleodb.org).

Georeferencing from free websites, such as the Global Gazetteer, version 2.2 (http://www. falingrain.com), was employed in the case of missing geographic coordinates. The modern geographic coordinates were converted in paleocoordinates using the software Point Tracker for Windows (Scotese 2008). 
The panbiogeographical method of track analysis was applied using ArcView v3.2 (ESRI 1999) with the extension Trazos2004 (Rojas 2007). It consisted of plotting the 223 occurrences on a map of 120 millions of years, provided by the Shapefile Library (Scotese 2008).

Overall, the method consists of connecting the occurrence points with lines, named individual tracks, using the criterion of minimum spanning trees. Individual tracks correspond to the geographical coordinates of taxon or the place where the evolution of this taxon occurred. After, these individual tracks are superimposed and when congruence is detected, generalized tracks are indicated. These latter indicate the existence of an ancestral biota that was fragmented by events such as climate change or tectonic processes. At the intersection or convergence of the generalized tracks biogeo- graphic nodes are verified. The nodes represent the intersection of different ancestral biotas and they are interpreted as hybrid areas (Craw et al. 1999, Grehan 2001, Heads 2004, Morrone 2004, 2009).

\section{RESULTS}

The overlapping of the 38 individual tracks (ITs) resulted in four generalized tracks (GTs) (Figure 1, Table I): GT1 (Northern Araripe), GT2 (Southern Araripe), GT3 (Trans-Gondwana) and GT4 (Seaway). From the intersection of the generalized tracks, three biogeographic nodes were found: Node A (Araripe) was formed by GT1 and GT2; Node B (Gondwanic) by GT1 and GT3; and Node C (Nigerian Seaway) by GT3 and GT4.

Fifty-eight taxa showed a single occurrence preventing their use in the track analysis (Table II). However, these records are important for

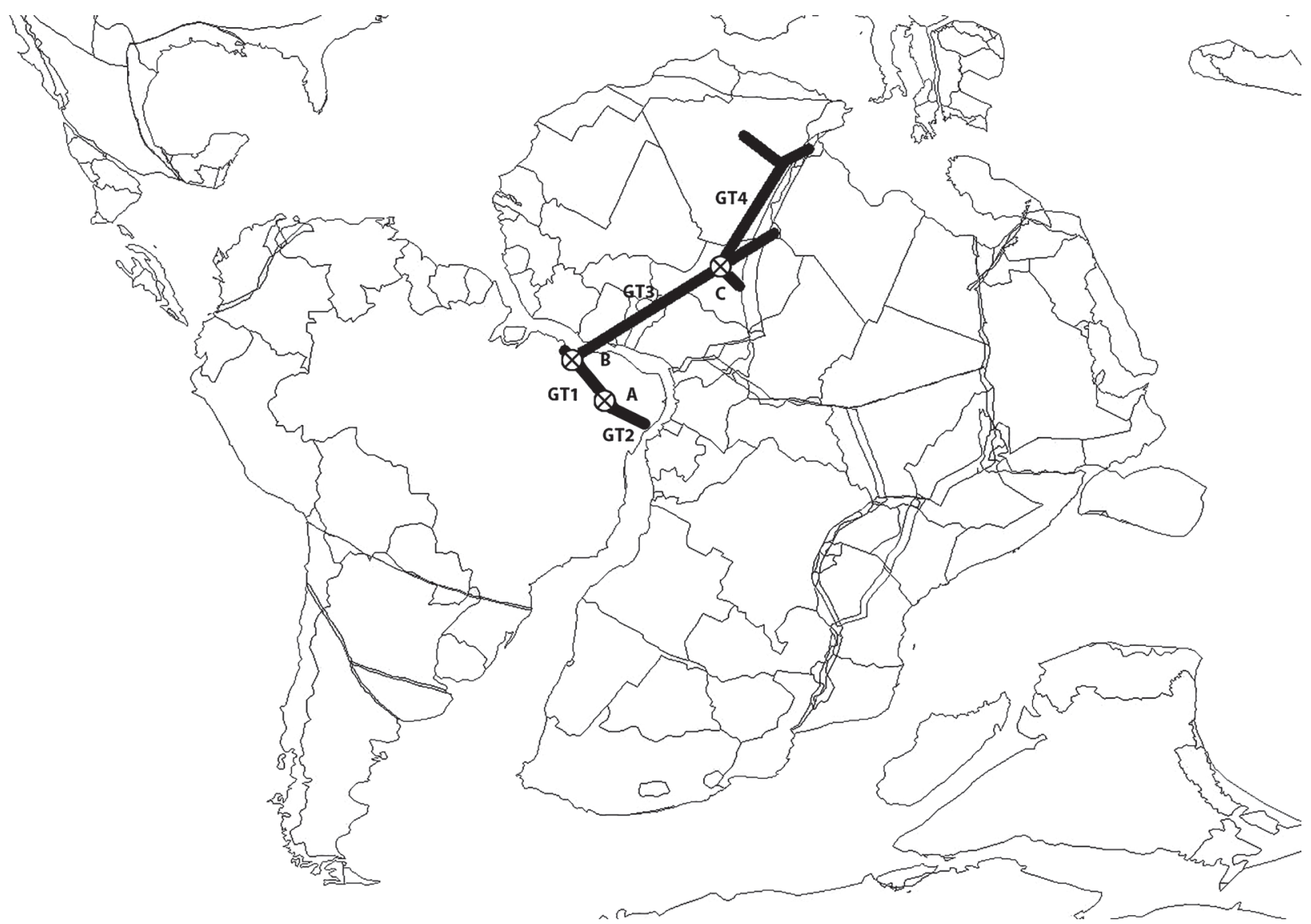

Figure 1 - Map showing the four generalized tracks and three biogeographic nodes. GT1 (Northern Araripe), GT2 (Southern Araripe), GT3 (Trans-Gondwana), GT4 (Marine Connection). Node A(Araripe), Node B (Gondwanic), Node C (Nigerian Seaway). 
TABLE I

Generalized Tracks (GTs), their respective locations (names) and Individual Tracks.

\begin{tabular}{|c|c|}
\hline Generalized Tracks & Individual Tracks \\
\hline GT1 (Northern Araripe) & Araripelepidotes temnurus, Brannerion latum, Calamopleurus cylindricus, Tharrhias rochae \\
\hline GT2 (Southern Araripe) & $\begin{array}{c}\text { Beurlenichthys ouricuriensis, Cladocyclus alagoensis, C. gardneri, Neoproscinetes penalvai, } \\
\text { Rhacolepis buccalis, Tharrhias araripis, Vinctifer longirostris }\end{array}$ \\
\hline GT3 (Trans-Gondwana) & Asiatoceratodus tiguidensis, Eotrigonodon sp., Neoceratodus africanus \\
\hline GT4 (Nigerian Seaway) & $\begin{array}{c}\text { Caturus sp., Cretodus sp., Hybodus sp., Lissodus sp., Mawsonia tegamensis, Mawsonia sp., } \\
\text { Onchopristis dunklei, O. numidus, Priohybodus arambourgi }\end{array}$ \\
\hline
\end{tabular}

TABLE II

Occurrences excluded from the Individual Tracks.

\begin{tabular}{|c|c|c|c|}
\hline Taxon & Brazil & Africa & References \\
\hline Asiatoceratodus sp. & $\mathrm{X}$ & & Castro et al. (2004), Toledo and Bertini (2005), Ramos et al. (2009) \\
\hline Asteracanthus sp. & & $\mathrm{X}$ & Murray (2000) \\
\hline Atractosteus africanus & & $\mathrm{X}$ & Murray (2000) \\
\hline Axelrodichthys maiseyi & $\mathrm{X}$ & & Carvalho et al. (2013) \\
\hline Axelrodichthys sp. & & $\mathrm{X}$ & Gee (1988) \\
\hline Bartschichthys sp. & $\mathrm{X}$ & & Ramos et al. (2009), Candeiro et al. (2011) \\
\hline Brannerion sp. & $\mathrm{X}$ & & Forey and Maisey $(2010)$ \\
\hline Britoichthys marizalensis & $\mathrm{X}$ & & Figueiredo (2004) \\
\hline Bullichthys santanensis & $\mathrm{X}$ & & Mayrinck et al. (2010) \\
\hline Casieroides yamangaensis & & $\mathrm{X}$ & Taverne (1975) \\
\hline Ceratodus humei & & $\mathrm{X}$ & Lefranc (1976) \\
\hline Ceratodus pectinatus & & $\mathrm{X}$ & Lefranc (1976) \\
\hline Ceratodus sp. & & $\mathrm{X}$ & Murray (2000) \\
\hline Chanopsis lombardi & & $\mathrm{X}$ & Casier (1961) \\
\hline Chardonius longicaudatus & & $\mathrm{X}$ & Murray (2000) \\
\hline Chirocentrites guinensis & & $\mathrm{X}$ & Cavin et al. (2013) \\
\hline Chiromystus mawsoni & $\mathrm{X}$ & & Silva Santos (1949) \\
\hline Clupavichthys dufouri & & $\mathrm{X}$ & Gayet (1989) \\
\hline Clupavus brasiliensis & $\mathrm{X}$ & & Silva Santos (1985b) \\
\hline Codoichthys carnavalii & $\mathrm{X}$ & & Silva Santos (1994), Figueiredo and Ribeiro (2016) \\
\hline Cratoamia gondwanica & $\mathrm{X}$ & & Brito et al. (2008) \\
\hline Cretodus semiplicatus & & $\mathrm{X}$ & Cuny et al. (2004) \\
\hline Dentilepisosteus laevis & $\mathrm{X}$ & & Grande (2010) \\
\hline Diabodus tataouinensis & & $\mathrm{X}$ & Cuny et al. (2004) \\
\hline Egertonodus sp. & & $\mathrm{X}$ & Cuny et al. (2010) \\
\hline Ellimma branneri & $\mathrm{X}$ & & Figueiredo (2006) \\
\hline Ellimma cruzae & $\mathrm{X}$ & & Silva Santos (1990), Figueiredo and Ribeiro (2016) \\
\hline Ellimmichthys goodi & & $\mathrm{X}$ & Eastman (1912) \\
\hline Ellimmicththys maceioensis & $\mathrm{X}$ & & Malabarba et al. (2004) \\
\hline Gyrodus sp. & & $\mathrm{X}$ & Cuny et al. (2010) \\
\hline Iansan beurleni & $\mathrm{X}$ & & Brito and Seret (1996) \\
\hline Iemanja palma & $\mathrm{X}$ & & Wenz (1989) \\
\hline Laeliichthys ancestralis & $\mathrm{X}$ & & Silva Santos (1985c) \\
\hline Lepidotes wenzae & $\mathrm{X}$ & & Brito and Gallo (2003) \\
\hline Leptostyrax macrorhiza & & $\mathrm{X}$ & Murray $(2000)$ \\
\hline
\end{tabular}


TABLE II (continuation)

\begin{tabular}{|c|c|c|c|}
\hline Taxon & Brazil & Africa & References \\
\hline Lupaceratodus useviaensis & & $\mathrm{X}$ & Gottfried et al. (2009) \\
\hline Mercediella riachuelensis & $\mathrm{X}$ & & Koerber (2012) \\
\hline Nanaichthys longipinnus & $\mathrm{X}$ & & Amaral and Brito (2012) \\
\hline Nolfia riachuelensis & $\mathrm{X}$ & & Figueiredo (2009) \\
\hline Notelops sp. & $\mathrm{X}$ & & Ramos et al. (2009) \\
\hline Obaichthys decoratus & $\mathrm{X}$ & & Wenz and Brito (1992), Grande (2010) \\
\hline Ogunichthys triangularis & $\mathrm{X}$ & & Alvarado-Ortega and Brito (2010) \\
\hline Oshunia brevis & $\mathrm{X}$ & & Wenz and Kellner (1986) \\
\hline Palaeonotopterus greenwoodi & & $\mathrm{X}$ & Taverne and Maisey (1999) \\
\hline Parachanos aethiopicus & & $\mathrm{X}$ & Arambourg and Schennegans (1935) \\
\hline Placidichthys tucanensis & $\mathrm{X}$ & & Brito and Alvarado-Ortega (2008) \\
\hline Pliodetes nigeriensis & & $\mathrm{X}$ & Wenz (1999) \\
\hline Proportheus kameruni & & $\mathrm{X}$ & Cavin et al. (2013) \\
\hline Pseudoleptolepis minor & & $\mathrm{X}$ & Taverne (1975) \\
\hline Ptychodus sp. & & $\mathrm{X}$ & Lefranc (1976) \\
\hline Rhacolepis latus & $\mathrm{X}$ & & Silva Santos (1985a) \\
\hline Santanasalmo elegans & $\mathrm{X}$ & & Gallo et al. (2009) \\
\hline Scapanorhynchus sp. & & $\mathrm{X}$ & Murray (2000) \\
\hline Stahlraja sertanensis & $\mathrm{X}$ & & Brito et al. (2013) \\
\hline Synechodus sp. & & $\mathrm{X}$ & Murray (2000) \\
\hline Tharrhias castellanoi & $\mathrm{X}$ & & Silva Santos (1963) \\
\hline Tribodus limae & $\mathrm{X}$ & & Brito and Ferreira (1989), Brito (1992) \\
\hline Tribodus tunisiensis & & $\mathrm{X}$ & Cuny et al. (2004) \\
\hline
\end{tabular}

understanding the Aptian-Albian fish faunas of those continents.

The individual tracks of Mawsonia lavocati, Calamopleurus africanus and Enchodus sp. did not form any generalized track. The same also applies to Dastilbe crandalli, Lepidotes sp., Mawsonia gigas, Santanichthys diasii and Vinctifer comptoni, because of their wide distribution in Western Gondwana.

The individual tracks of Araripichthys castilhoi, Axelrodichthys araripensis, Notelops brama, Paraelops cearensis, Placidichthys bidorsalis, Santanaclupea silvasantosi and Vinctifer araripensis are present in Node A.

\section{DISCUSSION AND CONCLUSIONS}

The large number of taxa (112) represented by 219 occurrences permits an overview of the paleoichthyofauna from Brazil and Africa during the Aptian-Albian. The 38 individual tracks obtained confirmed the great biodiversity in the range studied, as well as allowing the identification of distributional patterns.

In Brazil, most of the paleoichthyofauna was found in the Araripe Basin, which is considered an important Konservat Lagerstätte due to its diversity and the exceptional preservation of fossils.

In Africa, the majority of species occurs in the northwest region. This distribution can be explained by the intense tectonic processes during the AptianAlbian, such as the break-up of Gondwana and the opening of South Atlantic Ocean, as well as eustatic sea-level changes that resulted in the development of epicontinental seas.

Overall, the generalized tracks are associated with the break-up of Gondwana and with regional events such as the East Brazilian Rift System 
(EBRIS; Chang et al. 1992), that are related to this fragmentation.

Generalized tracks 1 and 2 (Figure 1) are located in the Araripe Basin and show the existence of two distinct faunas: one of which extended its distribution to the north (GT1 - Northern Araripe) and the other, to the south (GT2 - Southern Araripe).

The Node A (Figure 1), named here Araripe Node, is complex, because it possesses a mix of biota from GT1 and GT2, and also a local assemblage of fishes.

Maisey (2000) argued that the separation of South America and Africa occurred through many successive geologic events, rather than a single rifting event followed by simple rotational drifting (e.g., Szatmari et al. 1987, Popoff 1988). Popoff (1988) assumed a model for the South American Plate composed of at least three subplates exhibiting sequential and overlapping rift-drifting histories. This indicated rotational movement about an axis in the Ceará region suggested by Szatmari et al. (1987). This event would produce northerly compression between South America and Africa so that connections persisted through a long period of the Late Cretaceous. Szatmari et al. (1987) argued that compressional events on the equatorial Atlantic floor from the Late Cretaceous to Paleogene favored connections via oceanic islands formed from midocean ridges. As a result, many possibilities for vicariance and geodispersal arise.

Maisey (1993) stated that an event spanning about 100 million years, such as the tectonic separation between South America and Africa can be viewed as a causal factor in biogeographical analyses. Thus he claimed that other events of shorter temporal duration had more effective impact upon the biota. According to Maisey (1991), the region of Araripe Basin has sufficient data to indicate the existence of marine transgressions, extending from the Neocomian to the Aptian. This probably connected the northeast Brazilian rift basins to the interior basins, as well as the South and North Atlantic oceans (Martill et al. 2007), considering that marine ingressions continued through the Turonian (Maisey 1991) (Figure 2).

In addition, possible events of mass mortality of fishes that occurred during these transgressions may have been a result of abrupt changes in salinity associated with deoxygenation caused by the increase of microbial organisms (Martill et al. 2008, Saraiva 2008).

The generalized track 3 (Figure 1), named Trans-Gondwana, is located in the north center of Western Gondwana. This is consistent with widespread vicariant effects from Aptian-Albian, as the final break-up of Gondwana, which separated Africa from South America, with special emphasis on Brazil. Gondwana fragmentation was not produced by a single episode, but from a complex process involving a series of geological events such as several sequences of rifts (Maisey 2000). This event led not only to the separation of continents, but also the formation of South Atlantic Ocean. This process was identified by Souza-Lima et al. (2002) through an asynchronous sequence of geological events that affected the Brazilian eastern and equatorial margins.

The rifting occurred in two directions, from south to north on the Brazilian side and from west to east in the equatorial margin. The presence of a marine connection in the equatorial margin represents the extension of North Atlantic Ocean towards the south. This seaway clearly separated the paleoichthyofauna of Gondwana and Laurasia and replaced the Tethys Sea (Souza-Lima et al. 2002).

Maisey (2000) supported this approach and suggested that this new marine connection allowed marine organisms to extend their distributions to new areas. Arai (2009) pointed out that during the Aptian-Albian interval, Gondwana remained most of time flooded by marine transgressions, which would have allowed an exchange of marine fauna between Africa and Brazil. 


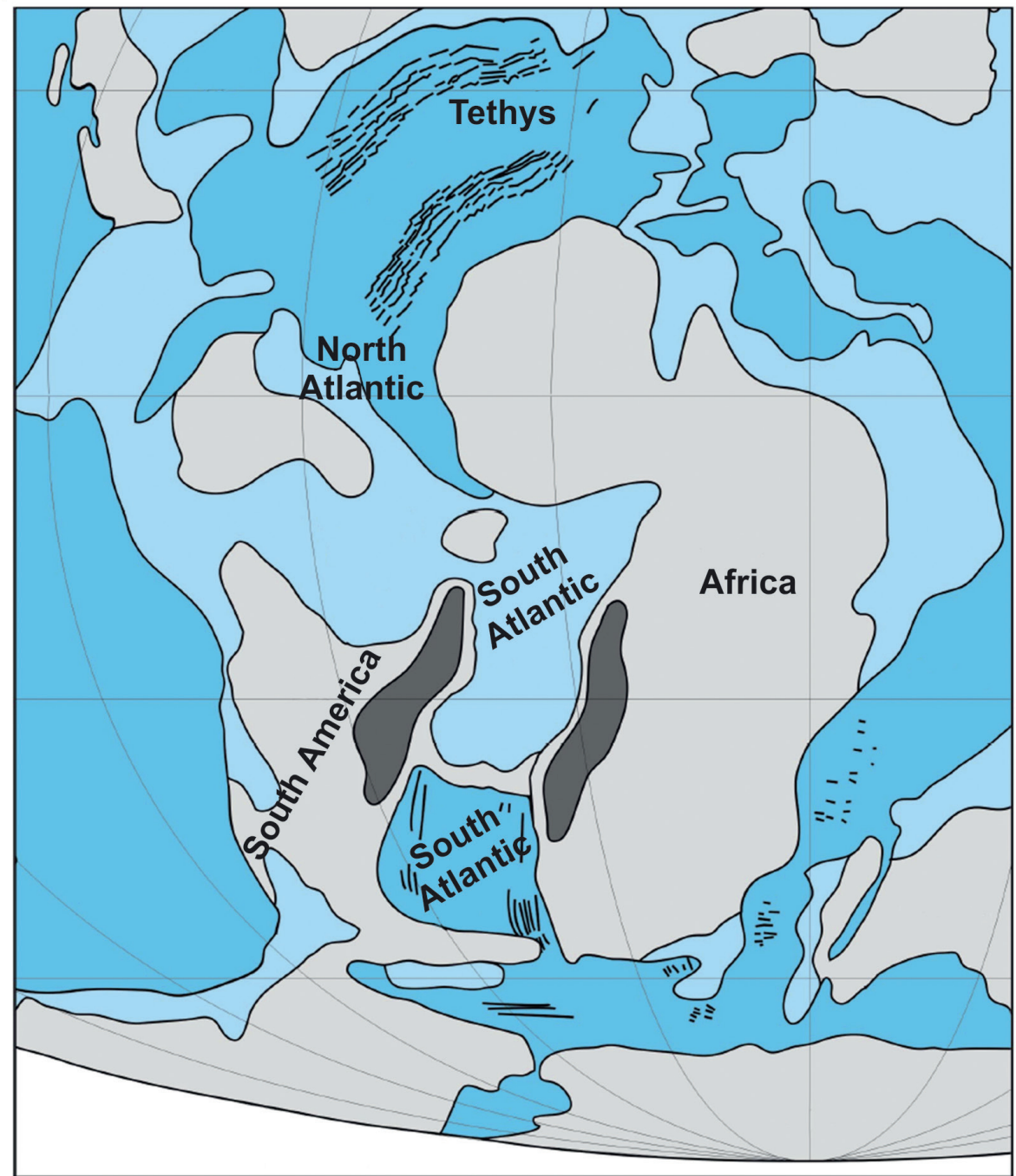

Figure 2 - Paleogeographic reconstruction of Atlantic Ocean in the Albian (modified from Azevedo 2004).

This could explain the similarity of the paleoichthyofauna of the two continents and the vicariant event that separated them.

The Gondwanic Node (Node B) obtained from the connection between generalized tracks 1 and 3 (Figure 1) is associated with the same vicariant event resulting from rifting, with GT1 representing the Brazilian biota and GT3 the African biota.

The GT4 (Figure 1) is located in the north of Western Gondwana and represents a probable local seaway produced by marine transgressions. Azevedo (2004) proposed a paleogeographical reconstruction for the Albian, adopting the base map of Hay et al. (1999). This reconstruction emphasized the existence of a shallow, intra or epicontinental sea on that region, corroborating the data herein obtained which support the existence of a marine connection, indicated by GT4 (Figure 3). Due to the break-up of South America and Africa, the waters of South Atlantic invaded the North and Central Atlantic, increasing resurgence and dispersion of hot and salty water, and stimulating biological productivity in other parts of oceans (Pletsch et al. 2001). Moreover, during the Albian, the South Atlantic was occupied by species from the Tethys Sea (Pletsch et al. 2001). 


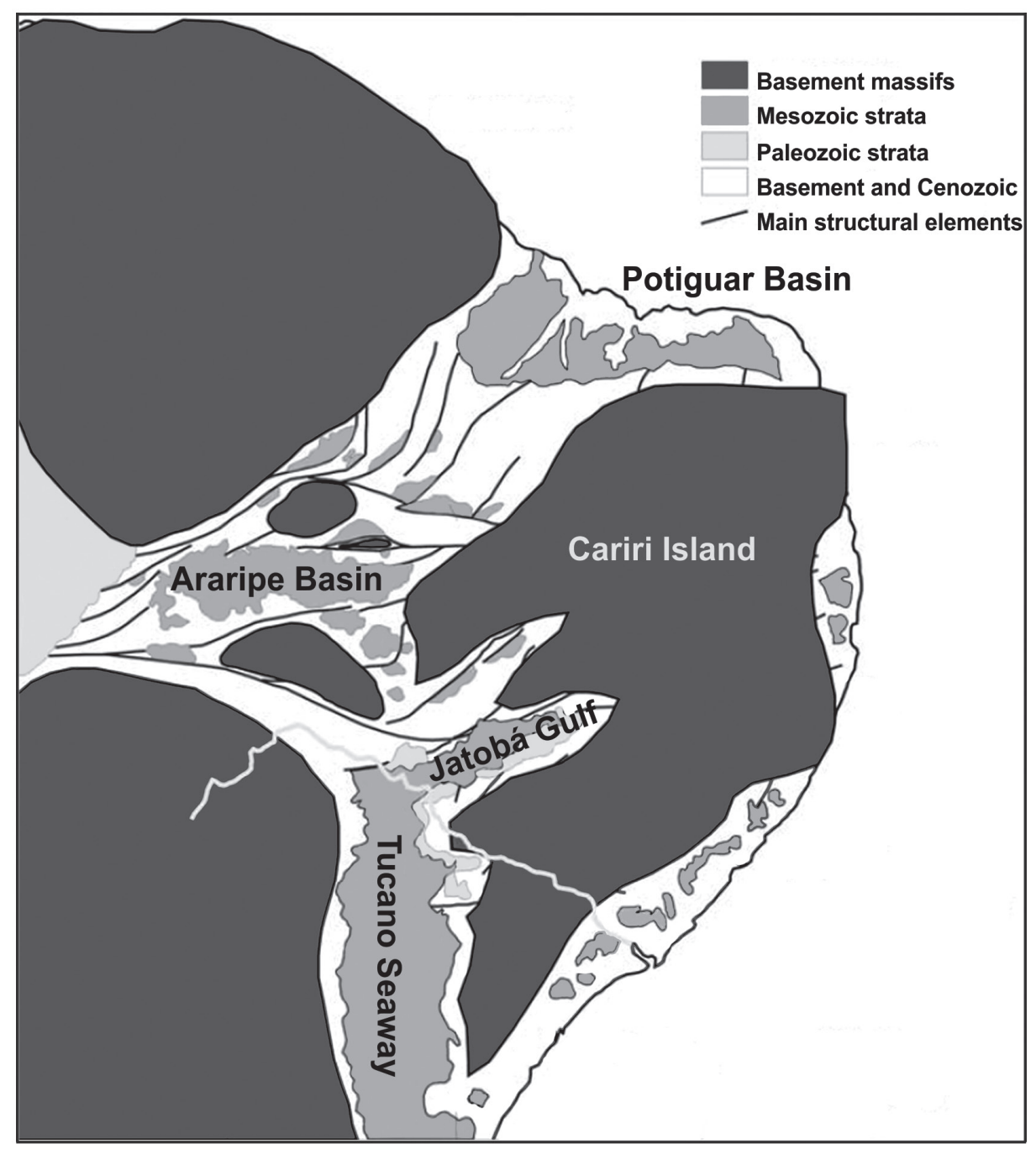

Figure 3 - Map showing possible intermittent marine connections between South and North Atlantic during Cretaceous (modified from Martill et al. 2007).

Several studies show the existence of a TransSaharan marine connection during Cenomanian and Turonian that connects the Tethys Sea and South Atlantic across the Sahara to West Africa. Simultaneously, the rising sea level caused the appearance of several other marine connections, including the Proto-North Atlantic (Gallo et al. 2007).

Pletsch et al. (2001) also supported this idea suggesting that there was a rising sea level in the South Atlantic during Cenomanian-Turonian. This transgression also produced an increase of nutrients and temperature and, consequently, improved the primary production (Herbert and Sarmiento 1991). However, the appearance of a Turonian marine connection could have started earlier than the Aptian-Albian, which could explain the existence of a huge fish fauna at this locality.

This can be explained if rising sea level and formation of epicontinental seas occurred as an intermittent process and not as a single event. Moreover, at the end of the Aptian, there was an equatorial marine connection between the North and South Atlantic and this epicontinental transgression continued until reaching its maximum extent in the Cenomanian and Turonian (Maisey 1991). 
The Node C (Nigerian Seaway), obtained by the intersection of generalized tracks 3 and 4 (Figure 1), can be related to the exchange of fauna due to the existence of epicontinental seas, in several parts of Gondwana, caused by marine transgressions occurred during the Aptian-Albian.

All data indicate that the generalized tracks and biogeographical nodes are associated with the great vicariant effect caused by the fragmentation of Gondwana.

\section{ACKNOWLEDGMENTS}

We are much indebted to Marise Sardenberg Salgado de Carvalho for valuable comments on earlier draft of the manuscript. We are also grateful to Michael Heads for his insightful review of the manuscript. This research is part of a project supported by the Conselho Nacional de Desenvolvimento Científico e Tecnológico (CNPq), Coordenação de Aperfeiçoamento de Pessoal de Nível Superior (CAPES) and the Fundação Carlos Chagas Filho de Amparo à Pesquisa do Estado do Rio de Janeiro (FAPERJ).

\section{REFERENCES}

AGASSIZ L. 1841. On the fossil fishes found by Mr Gardener in the Province of Ceará, in the north of Brazil. Edinburgh New Philos J 30: 82-84.

ALA MA AND SELLEY RC. 1997. The West African Coastal Basins. In: Selle RC (Ed), Sedimentary Basins of the World. African Basins, London: Imperial College of Science, Technology \& Medicine, Department of Geology, UK 3: 3-394.

ALVARADO-ORTEGA J AND BRITO PM. 2010. A new ichthyodectiform (Actinopterygii, Teleostei) from the Lower Cretaceous Marizal Formation, North-East Brazil. Palaeontology 53(2): 297-306.

AMARAL CRL AND BRITO PM. 2012. A New Chanidae (Ostariophysii: Gonorynchiformes) from the Cretaceous of Brazil with affinities to Laurasian gonorynchiforms from Spain. PLoS ONE 7(5): 1-9.

ANDERSON PE, BENTON MJ, TRUEMAN CN, PATERSON BAAND CUNY G. 2007. Paleoenvironments of the vertebrates on the southern shore of the Tethys:
The nonmarine Early Cretaceous of Tunisia. Palaeogeogr Palaeoclimatol Palaeoecol 243: 118-131.

ARAI M. 2009. Paleogeografia do Atlântico Sul no Aptiano: um novo modelo a partir de dados micropaleontológicos recentes. Bol Geoc PETROBRAS 17(2): 331-351.

ARAMBOURG CE AND SCHENNEGANS D. 1935. Poissons fossiles du bassin sédimentare du Gabon. Ann Paleontol 24: 137-160.

ASSINE ML. 2007. Bacia do Araripe. Bol Geoc PETROBRAS 15(2): 371-389.

AZEVEDO RLM. 2004. Paleoceanografia e a evolução do Atlântico Sul no Albiano. Bol Geoc PETROBRAS 12(2): 234-249.

BOUAZIZ S, BUFFETAUT E, GHANMI M, JAEGER JJ, MARTIN M, MAZIN JM AND TONG H. 1988. Nouvelles découvertes de vertébrés fossiles dans l'Albien du Sud tunisien. Bull Soc Géol Fr 4: 335-339.

BRITO PM. 1992. Nouvelles données sur l'anatomie et la position systématique de Tribodus limae Brito \& Ferreira, 1989 (Chondrichthyes, Elasmobranchii) du Crétacé inférieur de la Chapada do Araripe (N-E Brésil). Geobios 25(1): 143-150.

BRITO PM AND ALVARADO-ORTEGA J. 2008. A new species of Placidichthys (Halecomorphi: Ionoscopiformes) from the Lower Cretaceous Marizal Formation, northeastern Brazil, with a review of the biogeographical distribution of the Ophiopsidae. In: Cavin L, Longbottom A and Richter M (Eds), Fishes and the Break-up of Pangaea, London: Geological Society of London, Special Publications 295: 145-154.

BRITO PM AND FERREIRA PLN. 1989. The first hybodont shark, Tribodus limae n. g., n. sp., from the Lower Cretaceous of Chapada do Araripe (North-East Brazil). An Acad Bras Cienc 61: 53-57.

BRITO PM AND GALLO V. 2003. A new species of Lepidotes (Neopterygii: Semionotiformes: Semionotidae) from the Santana Formation, Lower Cretaceous of Northeastern Brazil. J Vertebr Paleontol 23(1): 47-53.

BRITO PM, LEAL MEC AND GALLO V. 2013. A new Lower Cretaceous guitarfish (Chondrichthyes, Batoidea) from the Santana Formation, Northeastern Brazil. Bol Mus Nac N S Geol 76: 1-13.

BRITO PM AND SERET B. 1996. The new genus lansan (Chondrichthyes, Rhinobatoidea) from the Early Cretaceous of Brazil and its phylogenetic relationships. In: Arratia G and Viohl G (Eds), Mesozoic Fishes - Systematics and Paleoecology, München: Verlag Dr. Friedrich Pfeil, p. 47-62.

BRITO PM, YABUMOTO Y AND GRANDE L. 2008. New Amiid Fish (Halecomorphi: Amiiformes) from the Lower Cretaceous Crato Formation, Araripe Basin, Northeastern Brazil. J Vertebr Paleontol 28(4): 1007-1014.

CANDEIRO CRA, FANTI F, THERRIEN F AND LAMANNA MC. 2011. Continental fossil vertebrates from the midCretaceous (Albian-Cenomanian) Alcântara Formation, 
Brazil, and their relationship with contemporaneous faunas from North Africa. J Afr Earth Sci 60(3): 79-92.

CARVAlHO CJB. 2009. Padrões de Endemismos e a conservação da biodiversidade. Megadiversidade 5(1-2): 77-86.

CARVALHO MSS, GALLO V AND SANTOS HRS. 2013. New species of coelacanth fish from the Lower Cretaceous (Albian) of the Grajaú Basin, NE Brazil. Cretaceous Res 46: 80-89.

CASIER E. 1961. Matériaux pour la faune ichthyologique éocrétacique du Congo. Ann Mus R Afr Cent, série in- $8^{\circ}$ 39: 1-96.

CASTRO DF, TOLEDO CEV, SOUSA EP AND MEDEIROS MA. 2004. Nova ocorrência de Asiatoceratodus (Osteichthyes, Dipnoiformes) na Formação Alcântara, Eocenomaniano da Bacia de São Luís, MA, Brasil. Rev Bras Paleontol 7(2): 245-248.

CAVIN L, FOREY PL AND GIERSCH S. 2013. Osteology of Eubiodectes libanicus (Pictet \& Humbert, 1866) and some other ichthyodectiformes (Teleostei): phylogenetic implications. J Syst Palaeontol 11(2): 115-177.

CHANG HK, KOWSMANN RO, FIGUEIREDO AMF AND BENDER AA. 1992. Tectonics and stratigraphy of the East Brazil Rift system: an overview. In: Ziegler PA (Ed), Geodynamics of Rifting, Volume II. Case History Studies on Rifts: North and South America and Africa. Tectonophysics 213: 97-138.

CÓRDOBA VC, JARDIM DE SÁ EF, SOUZA DC AND ANTUNES AF. 2007. Bacia de Pernambuco-Paraíba. Bol Geoc PETROBRAS 15(2): 391-403.

COSTA IP, BUENO GV, MILHOMEM PS, SILVA HSRL AND KOSIN MD. 2007a. Sub-bacia de Tucano Norte e Bacia de Jatobá. Bol Geoc PETROBRAS 15(2): 445-453.

COSTA IP, MILHOMEM PS, BUENO GV, SILVA HSRL AND KOSIN MD. 2007b. Sub-bacias de Tucano Sul e Central. Bol Geoc PETROBRAS 15(2): 433-443.

CRAW RC, GREHAN JR AND HEADS MJ. 1999. Panbiogeography: tracking the history of life. Oxford Biogeography Series 11, New York and Oxford: Oxford University Press, $229 \mathrm{p}$.

CRISCI JV. 2001. The voice of Historical Biogeography. J Biogeogr 28(2): 157-168.

CROIZAT L. 1958. Panbiogeography. Vols. 1 and 2. Caracas: Published by the author, $1731 \mathrm{p}$.

CROIZAT L. 1964. Space, time, form: The biological synthesis. Caracas: Published by the author, $881 \mathrm{p}$.

CUNY G, COBBET AM, MEUNIER FJ AND BENTON MJ. 2010. Vertebrate microremains from the Early Cretaceous of southern Tunisia. Geobios 43: 615-628.

CUNY G, OUAJA M, SRARFI D, SCHMITZ L, BUFFETUT E AND BENTON MJ. 2004. Fossil sharks from the Early Cretaceous of Tunisia. Rev Paléobiol 9: 127-142.

EASTMAN CR. 1912. Tertiary fish-remains from Spanish Guinea in west Africa. Ann Carn Mus 8: 370-378
ESRI INC. 1999. ArcView GIS version 3.2 for Windows. Environmental Systems Research Institute, Redlands.

FIGUEIREDO FJ. 2004. A new euteleostean fish from the Lower Cretaceous of Tucano Basin, north-eastern Brazil. Arq Mus Nac 62(3): 293-307.

FIGUEIREDO FJ. 2006. Morfologia e Sistemática de peixes teleósteos do Cretáceo e Terciário do Nordeste do Brasil atribuídos aos Clupeomorpha. Tese de Doutorado, Museu Nacional/UFRJ, 2 Vols, 326 p.

FIGUEIREDO FJ. 2009. A new marine clupeoid fish from the Lower Cretaceous of the SergipeAlagoas Basin, northeastern Brazil. Zootaxa 2164: 21-32.

FIGUEIREDO FJ AND GALLO V. 2004. A New Teleost fish from the early Cretaceous of Northeastern Brazil. Bol Mus Nac N S Geol 73: 1-23.

FIGUEIREDO FJ AND RIBEIRO DRM. 2016. Relationships of + Codoichthys carnavalii Santos, 1994 (Teleostei, Clupeomorpha, †Ellimmichthyiformes) from the Late Aptian of São Luís-Grajaú Basin, Ne Brazil. An Acad Bras Cienc 88: 1277-1307.

FOREY PL AND MAISEY JG. 2010. Structure and relationships of $\uparrow$ Brannerion (Albuloidei), an Early Cretaceous teleost from Brazil. In: Nelson JS, Schultze HP and Wilson MVH (Eds), Origin and Phylogenetic Interrelationships of Teleosts, München: Verlag Dr. Friedrich Pfeil, p. 183-218.

GALLO V, CAVALCANTI MJ AND SILVA HMA. 2007. Track analysis of the marine palaeofauna from the Turonian (Late Cretaceous). J Biogeogr 34(7): 1167-1172.

GALLO V AND FIGUEIREDO FJ. 2010. Paleobiogeografia. In: Carvalho IS (Org), Paleontologia: Conceitos e Métodos, Rio de Janeiro: Interciência, $3^{\text {a }}$ ed. 1: 351-370.

GALLO V, FIGUEIREDO FJ AND AZEVEDO SA. 2009. Santanasalmo elegans gen. et sp. nov., a basal euteleostean fish from the Lower Cretaceous of the Araripe Basin, northeastern Brazil. Cretaceous Res 30(6): 1357-1366.

GAYET M. 1989. Note préliminaire sur le matériel paléoichthyologique éocrétacique du Rio Benito (sud de Bata, Guinée Equatoriale). Bull Mus Natn Hist Nat, $4^{\mathrm{e}}$ sér., 11, sect. C (1): 21-31.

GEE H. 1988. Cretaceous unity and diversity. Nature 332(6164): 487.

GOTTFRIED MD, STEVENS NJ, ROBERTS EM, O'CONNOR PM AND CHAMI R. 2009. A new Cretaceous lungfish (Dipnoi: Ceratodontidae) from the Rukwa Rift Basin, Tanzania. Afr Nat Hist 5: 31-36.

GRANDE L. 2010. An empirical synthetic pattern study of gars and closely related species (Lepisosteiformes) based mostly on skeletal anatomy: The resurrection of Holostei. American Society of Ichthyologists and Herpetologists, Special Publication 7, Allen Press, 874 p.

GREHAN JR. 2001. Panbiogeografía y la geografía de la vida. In: Llorente J and Morrone JJ (Eds), Introduccíon a la biogeografía em Latinoamérica: teorías, conceptos, métodos y aplicaciones. México D.F.: UNAM: Las Prensas de Ciencias, p. 181-195. 
GREIGERT J. 1966. Description des formations Crétacés et Tertiaires du Basin de Iullemmeden. Mém Bur Rech géol $\min 2: 1-234$.

HAY WW ET AL. 1999. Alternative global Cretaceous paleogeography. In: Barrera E and Johnson CC ( Eds), Evolution of the Cretaceous Ocean-Climate System. Boulder, Colorado, Geological Society of America Special Paper, 332.

HEADS M. 2004. What is a node? J Biogeogr 31: 1883-1891.

HERBERT TD AND SARMIENTO JL. 1991. Ocean nutrient distribution and oxygenation: limits on the formation of warm saline botton water over the past 91 m.y. Geology 19: 702-705.

JORDAN DS. 1910. Description of a collection of fossil fishes from the bituminous shales at Riacho Doce, state of Alagoas, Brazil. Ann Carn Mus 7(1): 23-24.

JORDAN DS. 1919. New genera of fossil fishes from Brazil. Proc Acad Nat Sci 71: 208-210.

JORDAN DS AND BRANNER J. 1908. The Cretaceous fishes of Ceará, Brazil. Smith Misc Coll 5(52): 1-29.

KOERBER S. 2012. Mercediella nom. nov., a replacement name for Camposichthys Figueiredo \& Silva Santos, 1991 (Pisces: Pycnodontiformes). Bonn Zool Bull 61(1): 29-30.

LEFRANC JP. 1976. État des connaissances actuelles sur les zonations biostratigraphiques du milieu du Crétacé (Albien-Turonien) au Sahara. Ann Mus Hist Nat Nice 4(19): 1-19.

LUNDBERG J. 1993. African-South American freshwater fish clades and continental drift: problems with a paradigm. p. 156-199. In: Goldblatt P (Ed), Biological Relationships between Africa and South America. New Haven: Yale University Press, $630 \mathrm{p}$.

MAISEY JG. 1991. Santana Fossils: An illustrated atlas. New Jersey, TFH Publications: Neptune, 459 p.

MAISEY JG. 1993. Tectonics, the Santana Lagerstäten, and implications for Late Gondwanan Biogeography. p. 435-454. In: Goldblatt P (Ed), Biological Relationships between Africa and South America. New Haven: Yale University Press, $630 \mathrm{p}$.

MAISEY JG. 2000. Continental break up and the distribution of fishes of Western Gondwana during the Early Cretaceous. Cretaceous Res 21: 281-314.

MALABARBA MCSL, CARMO DA, GOMEZ-PEREZ I AND QUEIROZ-NETO JV. 2004. A new clupeomorph fish from the Cretaceous Maceió Formation, Alagoas Basin, NE Brazil. Neues Jahrb Geol Palaontol Abh 233(2): 255-274.

MARTILL, DM, BECHLY G AND LOVERIDGE RF. 2007. The Crato Fossil Beds of Brazil. Window into an Ancient World. Cambridge University Press: Cambridge, New York, Melbourne, $625 \mathrm{p}$.

MARTILL DM, BRITO PM AND EVANS JW. 2008. Mass mortality of fishes in the Santana Formation (Lower Cretaceous, ?Albian) of northeast Brazil. Cretaceous Res 29: 649-658.

MAYRINCK D, BRITO PM AND OTERO O. 2010. A new albuliform (Teleostei: Elopomorpha) from the Lower
Cretaceous Santana Formation, Araripe Basin, northeastern Brazil. Cretaceous Res 31: 227-236.

MIGUEL R, GALLO V AND MORRONE JJ. 2014. Distributional patterns of $\uparrow$ Mawsoniidae (Sarcopterygii: Actinistia). An Acad Bras Cienc 86: 159-170.

MOODY RTJ AND SUTCLIFFE JP. 1991. The Cretaceous deposits of the Iullemmeden Basin of Niger, Central West Africa. Cretaceous Res 12: 137-157.

MORRONE JJ. 2004. Panbiogeografía: componentes bióticos y zonas de transición. Rev Bras Entomo 48: 149-162.

MORRONE JJ. 2009. Evolutionary Biogeography: An integrative approach with case studies. New York: Columbia University Press, 301 p.

MORRONE JJ AND CRISCI JV. 1995. Historical Biogeography: Introduction to Methods. Annu Rev Ecol Evol Syst 26: 373-401.

MURRAY AM. 2000. The Palaeozoic, Mesozoic and Early Cenozoic fishes of Africa. Fish and Fisheries 1: 111-145.

NETO OCP, SOARES UM, DA SILVA JGF, ROESNER EH, FLORENCIO CP AND DE SOUZA CAV. 2007a. Bacia Potiguar. Bol Geoc PETROBRAS 15(2): 357-369.

NETO OPAC, SOUZA LIMA W AND CRUZ FEG. 2007b. Bacia de Sergipe-Alagoas. Bol Geoc PETROBRAS 15(2): 405-415.

PLESTCH T, ERBACHER J, HOLBOURN AEL, KUHNT W, MOULLADE M, OBOH-IKUENOBEDED FE, SÖDINGE E AND WAGNERF T. 2001. Cretaceous separation of Africa and South America: the view from the West African margin (ODP Leg 159). J South Am Earth Sci 14: 147-174.

POPOFF M. 1988. Du Gondwana à l' Atlantique sud: Les connexions du fossé de las Bénoué avec les bassins du Nord-est brésilien jusqu'a l'overture du Golfe de Guinée au Crétacé inférieur. p. 409-431. In: Sougy J and Rodgers J (Eds), The West African Connection. J Afr Earth Sci Spec Publ 7(2).

RAMOS MIF, SANTOS HMM, COSTA SARF AND TOLEDO PM. 2009. Catálogo de Fósseis: Coleção Paleontológica do Museu Paraense Emílio Goeldi. Mus Para Emílio Goeldi, Belém, 172 p.

ROBERTS EM, O'CONNOR PM, STEVENS NJ, GOTTFRIED MD, JINNAH ZA, NGASALA S, CHOH AM AND ARMSTRONG RA. 2010. Sedimentology and depositional environments of the Red Sandstone Group, Rukwa Rift Basin, southwestern Tanzania: New insight into Cretaceous and Paleogene terrestrial ecosystems and tectonics in sub-equatorial Africa. J Afr Earth Sci 57: 179212.

ROJAS CA. 2007. Una herramienta automatizada para realizar analisis panbiogeograficos. Biogeografía 1: 31-33.

SANTOS MECM AND CARVALHO MSS. 2009. Paleontologia das bacias do Parnaíba, Grajaú e São Luís. Reconstituições Paleobiológicas. CPRM Serviço Geológico do Brasil DGM/DIPALE, Rio de Janeiro, 215 p. 
SARAIVAAAF. 2008. Caracterização paleoambiental e paleooceanográfica da Formação Romualdo, Bacia sedimentar do Araripe. Tese (Doutorado). Universidade Federal de Pernambuco. Centro de Tecnologia e Geociências, Departamento de Oceanografia, Recife.

SCHAEFFER B. 1947. The Cretaceous and Tertiary actinopterygian fishes from Brazil. Bull Am Mus Nat Hist 89(1): $1-40$.

SCOTESE CR. 2008. The PALEOMAP Project paleoatlas for ArcGIS. Volume 2, Cretaceous paleogeographic and plate tectonic reconstructions. PALEOMAP Project, Arlington, Texas.

SILVA HMA AND GALLO V. 2007. Parsimony analysis of endemicity of enchodontoid fishes from the Cenomanian. Carnets Geol Letter, p. 1-8.

SILVA SANTOS R. 1949. Sobre Peixes Fósseis Chiromystus, da ilha de Itaparica, Bahia. Not Prel DGM/DNPM 50(1949): 1-12.

SILVA SANTOS R. 1963. Peixes do Cretácico do Rio Grande do Norte. An Acad Bras Cienc 35: 67-74.

SILVA SANTOS R. 1985a. A ictiofáunula da Formação Riachuelo, Estado de Sergipe. In: Campos DA, Ferreira CS, Brito IM and Viana CF (Orgs), Coletânea de Trabalhos Paleontológicos. Departamento Nacional da Produção Mineral, Brasília, p. 141-145.

SILVA SANTOS R. 1985b. Clupavus brasiliensis n. sp. (Teleostei Clupeiformes) do Cretáceo Inferior, Formação Marizal, Estado da Bahia. In: Campos DA, Ferreira CS, Brito IM and Viana CF (Orgs), Coletânea de Trabalhos Paleontológicos. Departamento Nacional da Produção Mineral, Brasília, p. 155-159.

SILVA SANTOS R. 1985c. Laeliichthys ancestralis, novo gênero e espécie de Osteoglossiformes do Aptiano da Formação Areado, Estado de Minas Gerais, Brasil. In: Campos DA, Ferreira CS, Brito IM and Viana CF (Orgs), Coletânea de Trabalhos Paleontológicos. Departamento Nacional da Produção Mineral, Brasília, p. 161-167.

SILVA SANTOS R. 1990. Clupeiformes e Gonorhynchiformes do Cretáceo Inferior (Aptiano) da Formação Cabo, Nordeste do Brasil. An Acad Bras Cienc 62: 261-268.

SILVA SANTOS R. 1994. Ictiofáunula da Formação Codó, Cretáceo Inferior, com a Descrição de um Novo Táxon Codoichthys carnavalii. An Acad Bras Cienc 66: 131-143.

SOUZA-LIMA W. 2006. Plataformas Carbonáticas Cretáceas das Bacias da Margem Leste Brasileira: O Registro da Implantação do Oceano Atlântico Sul. Bol Soc Bras Paleo 53.

SOUZA-LIMA W. 2007. Do mar proterozóico da Serra de Itabaiana ao mar mioceno de Tabocas - o litoral de Sergipe ao longo do tempo. In: Souza-Lima W, Manso CL de C (Coord), Paleo 2007, Itabaiana, Sergipe, 2007. Fundação Paleontológica Phoenix, Universidade Federal de Sergipe, Resumos, p. 8.

SOUZA-LIMA W, ANDRADE EJ, BENGTSON P AND GALM PC. 2002. A bacia de Sergipe-Alagoas: evolução geológica, estratigrafia e conteúdo fóssil. Fundação Paleontológica Phoenix, Edição especial 1, 34 p.

SZATMARI P, FRANÇOLIN BL, ZANOTO O AND WOLFF S. 1987. Evolução tectônica da margem equatorial brasileira. Rev Bras Geoc 17(2): 180-188.

TAVERNE L. 1975. Étude complémentaire de Wenzia congolensis (Arambourg, C., et Schnéegans, D., 1935), Téléostéen Salmoniforme fossile du Wealdien du Gabon, précédemment décrit dans le genre Leptolepis Agassiz, L., 1832. Bull Mus Nat His Nat, $3^{\mathrm{e}}$ série, p. 229-240.

TAVERNE L AND MAISEY JG. 1999. A notopterid skull (Teleostei, Osteoglossomorpha) from the continental early Cretaceous of southern Morroco. Am Mus Novit 3260: $1-12$.

TOLEDO CEV AND BERTINI RJ. 2005. Occurrences of the fossil Dipnoiformes in Brazil and it's Stratigraphic and Chronological Distributions. Rev Bras Paleontol 8(1): 4756.

UPCHURCH P. 2008. Gondwanan break-up: legacies of a lost world? Trends Ecol Evol 23(4): 229-236.

VAZ PT, REZENDE NGAM, WANDERLEY FILHO JR AND TRAVASSOS WAS. 2007. Bacia do Parnaíba. Bol Geoc PETROBRAS 15(2): 253-263.

WENZ S. 1989. Iemanja palma n.g.,n.sp., Gyrodontidae noveau (Pisces, Actinopterygii) du Crétacé inférieur de la Chapada do Araripe (N-E du Brésil). C R Acad Sci Paris: 975-980.

WENZ S. 1999. Pliodetes nigeriensis gen. nov. et sp. nov., a new semionotid fish form the Lower Cretaceous of Gadoufaoua (Niger Republic): phylogenetic comments. In: Arratia G and Schultze HP (Eds), Mesozoic fishes 2 - Systematics and fossil record, München: Verlag Dr. Friedrich Pfeil, p. 107-120.

WENZ S AND BRITO PM. 1992. Première découverte de Lepisosteidae (Pisces, Actinopterygii) dans le Crétacé inférieur de la Chapada do Araripe (N-E du Brésil): Conséquences sur la phylogénie des Ginglymodi. IC R Acad Sci Paris 314(II): 1519-1525.

WENZ S AND KELLNER AWA. 1986. Découverte du premier Ionoscopidae (Pisces, Halecomorphi) sud-americain, Oshunia brevis n. g., n. sp., dans le Crétacé inférieur de la Chapada do Araripe (nord-est du Brésil): Bull Mus Nat His Nat Paris 4(1): 77-88.

WOODWARD AS. 1908. On some fossil fishes discovered by Prof. Ennes de Souza in the Cretaceous Formation at Ilheus (state of Bahia), Brazil. Q J Geol Soc Lond 64: 358-362.

ZALÁN PV. 2007. Bacias de Bragança-Viseu, São Luís e Ilha Nova. Bol Geoc PETROBRAS 15(2): 341-345.

ZALÁN PV AND SILVA PCR. 2007. Bacia do São Francisco. Bol Geoc PETROBRAS 15(2): 561-571.

ZARBOUT M, SOUQUET P AND PEYBERNES B. 1994. Séquences de dépôt dans les environnements de transition fluviatile-marin de Crétacé inférieur de Dahar (SudTunisien). Strata 6: 141-142. 